\title{
THE IMPORTANCE OF THE RESISTANCE TO WEAR IN THE CHOICE OF FABRICS FOR PROTECTIVE GARMENTS
}

Nataša Radmanovac“, Nenad Ćirković, Tatjana Šarac

Faculty of Technology, University of Niš, Leskovac, Serbia

Wear resistance, as one of typical characteristics, is used for evaluating the durability of textile materials in use and their suitability for the intended purpose. In this paper the results of the Martindale method of wear of fabric intended for making protective and work clothing are presented. The fabric wear is done with sandpaper on a flat surface, at different cycles, by monitoring the changes in weight and by visual comparison. With the increase of the number of cycles of wear it can be seen that the percentage weight loss of samples increases due to uprooting of fibers from the surface, and also the damages can occur which can be seen in the intermittent occurrence of yarn breakage and holes in the fabric.
(ORIGINAL SCIENTIFIC PAPER) UDC 687.17:677.017

Keywords: fabric, wear, abrasive material, weight change

\section{Introduction}

The increasing production of protective equipment that requires increased security for work in harsh operating conditions has led to the development of the fabric with high resistance to wear, with the improvement of other features. Protective clothing for workers, soldiers, police officers, firefighters and others is exposed to daily wear and in specific areas (elbows, shoulders, knees, the edges of legs and the like.), so it is necessary that it is highly resistant to abrasion. Wear is only one of the factors that influence the shabbiness i.e., the durability of the fabric [1, 2].

The resistance to abrasion and friction of the fabric is a very complex concept because during the use of clothing, different stresses, friction and wear emerge. This resistance is important because it enables a longer lifetime when wearing clothes. It is similar to surface products for bedding, furniture and technical purposes. The abrasion resistance is the resistance by which the fabric or other textile material opposes the deterioration due to wear under certain conditions. Taking into account the degree of changes on the surface of the fabric which can be reflected in changes of physical properties and changes in the structure of the fabric, it is estimated by measuring the following characteristics [3]:

- mass loss,

- strength loss,

- increase of air permeability,

- increase of light permeability,

- reduction of thickness,

- changes in surface appearance (yarn breakage, holes).

The resistance of textile materials to wear is influenced by the following factors:

- fabric properties (hairiness, smoothness, finishing, construction, structure, etc.),

- properties of the space in which the testing is done (humidity, temperature),
- the testing procedure (sample tension; pressure preload; the way of wear

- longitudinal, circular; tear direction; duration of wear; type of abrasive agent).

The damage to the fabric in wear is usually due to the weakening of the structure caused by mechanical breaking of individual fibers. Fiber breakages are the result of a large number of bending and abrasion of the material during wear. The fibers on the surface are held only loosely and are the subject only to a mild wear $[3,4]$.

\section{Materials and methods}

Fabrics used. For testing the wear resistance of fabrics, eleven different cotton fabrics were selected and one from a mixture of cotton and polyester fiber intended for the production of protective work clothing (military, police, firefighters, construction workers, car mechanics, electricians, etc.). All fabrics were dyed and finished by the same agents and in a conventional way for fabrics for this purpose. Technical characteristics of the fabric, according to SRPS F.C0.011, SRPS F.C0.012 and ISO 2959 are given in Table 1.

Abrasive material. For the abrasion of the fabrics, the following abrasive material was used: emery paper from the Greek producer Smirdex®, two different types (dry emery paper and waterproof emery paper) and with different grit sizes $(P)$ defined according to ISO 6344 standard:

- Dry sanding emery 510: P240, P180, P150, P120, P80;

- Waterproof emery 270: P500, P360, P240, P180.

The diameter of the sandpaper used to treat the fabric was $3 \mathrm{~cm}$ (area $7 \mathrm{~cm}^{2}$ ).

Preparation of the samples. The samples were taken from used materials (fabrics) in accordance with the SRPS EN 12751 standard. This standard defines the conditions, places and quantities of the material necessary for the analysis.

Testing equipment. To test the wear resistance of the

\footnotetext{
* Author address: Nataša Radmanovac, Faculty of Technology, University of Niš, Bulevar oslobodjenja 124, 16000 Leskovac, Serbia

E-mail: radmanovac@tf.ni.ac.rs,nradmanovac@gmail.com

The manuscript received: March, 13, 2017.

Paper accepted: March, 21, 2017.
} 
Table 1. Technical characteristics of the fabric

\begin{tabular}{|c|c|c|c|c|c|c|c|c|}
\hline \multirow{3}{*}{$\begin{array}{c}\text { Fabric } \\
N_{0}\end{array}$} & \multirow{2}{*}{\multicolumn{2}{|c|}{$\begin{array}{c}\text { Yarn length count } \\
T_{t} \text { (tex) }\end{array}$}} & \multirow{2}{*}{\multicolumn{2}{|c|}{$\begin{array}{c}\text { Yarn composition } \\
(\%)\end{array}$}} & \multicolumn{2}{|c|}{ Count } & \multirow{3}{*}{$\begin{array}{c}\text { Surface } \\
\text { mass } \\
M\left(g \cdot \mathbf{m}^{-2}\right)\end{array}$} & \multirow{3}{*}{ Weave } \\
\hline & & & & & \multirow{2}{*}{$\underset{\text { gorp }}{\text { warp }\left(\mathrm{cm}^{-1}\right)}$} & \multirow{2}{*}{$\begin{array}{c}\text { weft } \\
g_{p}\left(\mathrm{~cm}^{-1}\right)\end{array}$} & & \\
\hline & warp & weft & warp & weft & & & & \\
\hline 1 & $32 \times 2$ & $32 \times 2$ & $100 \mathrm{Co}$ & $100 \mathrm{Co}$ & 25 & 18 & 305 & plain \\
\hline 2 & $64 \times 2$ & 64 & $100 \mathrm{Co}$ & $100 \mathrm{Co}$ & 16 & 15 & 305 & plain \\
\hline 3 & $48 \times 2$ & $50 \times 2$ & $100 \mathrm{Co}$ & $100 \mathrm{Co}$ & 20 & 14 & 375 & plain \\
\hline 4 & $18 \times 2$ & $15 \times 2$ & $\begin{array}{l}50 / 50 \\
\text { Co/PES }\end{array}$ & $\begin{array}{l}50 / 50 \\
\text { Co/PES }\end{array}$ & 36 & 26 & 250 & $\mathrm{~K} 2 / 1 \mathrm{z}$ \\
\hline 5 & $18 \times 2$ & $25 \times 2$ & $100 \mathrm{Co}$ & 100 Co & 46 & 24 & 295 & $\mathrm{~K} 3 / 1 \mathrm{z}$ \\
\hline 6 & 30 & 42 & $100 \mathrm{Co}$ & $100 \mathrm{Co}$ & 49 & 24 & 270 & $\mathrm{~K} 3 / 1 \mathrm{z}$ \\
\hline 7 & 30 & 72 & $100 \mathrm{Co}$ & $100 \mathrm{Co}$ & 48 & 21 & 325 & $\mathrm{~K} 3 / 1 \mathrm{z}$ \\
\hline 8 & 36 & 56 & $100 \mathrm{Co}$ & $100 \mathrm{Co}$ & 35 & 18 & 245 & $\mathrm{~K} 2 / 2 \mathrm{~s}$ \\
\hline 9 & $30 \times 2$ & 64 & $100 \mathrm{Co}$ & $100 \mathrm{Co}$ & 27 & 16 & 295 & $\mathrm{~K} 2 / 2 \mathrm{~s}$ \\
\hline 10 & 34 & 72 & $100 \mathrm{Co}$ & $100 \mathrm{Co}$ & 43 & 23 & 315 & P $2 / 2$ \\
\hline 11 & $24 \times 2$ & 42 & $100 \mathrm{Co}$ & $100 \mathrm{Co}$ & 36 & 34 & 320 & 5 harness satin \\
\hline 12 & 34 & $34 \times 2$ & $100 \mathrm{Co}$ & $100 \mathrm{Co}$ & 44 & 22 & 345 & 5 harness satin \\
\hline
\end{tabular}

fabric, the following instruments and apparatus were used:

- Analytical balance for weighing fabric samples, Denver Instrument AA-160,

- Fabric sample circle cutter, James Heal Cutter 230/140 (samples diameter $14 \mathrm{~cm}$, area of fabric samples $154 \mathrm{~cm}^{2}$ ),

- Abrasive tester for fabric abrasion, James Heal 900, model 905 (fabric sample friction surface $79 \mathrm{~cm}^{2}$ ).

Testing method.

Testing of the fabric characteristics in wear resistance was conducted using the method described in SRPS EN ISO $12947(1-4)$ [5]. The testing was conducted at 50, 100, 200, 300, 400, 500, 700, and 1000 cycles. The pressure of the abrasive material on the fabric wais $12 \mathrm{kPa}$, and the wear method was circular (Lissajous figure) [6, 7]. After each cycle of abrasion, pulled up fibers were collected on the surface of the fabric, which should be carefully cleaned and then its mass was measured [4]. Based on the difference in mass, the percentage of the weight loss was calculated after each cycle of abrasion according to the formula:
$\Delta \mathrm{P}_{\mathrm{m} 50 \div 1000}=\frac{\Delta \mathrm{m}_{50 \div 1000}}{\mathrm{~m}_{\mathrm{o}}} \cdot 100(\%)$

where $\Delta P_{m 50 \div 1000}$ - is the percentage of the mass change of the fabric sample (mass loss) after each abrasion cycle (\%),

$\Delta \mathrm{m}_{50 \div 1000}$ - is the change of the fabric sample weight after each abrasion cycle $(\mathrm{g})$ :

$\Delta m_{50 \div 1000}=m_{u z}-m_{50 \div 1000}(\mathrm{~g})$

$\mathrm{m}_{0}$ - is the mass of the fabric sample calculated with respect to the friction surface of the material,

$\mathrm{m}_{\mathrm{uz}}$ - is the mass of the fabric sample before abrasion ( $\mathrm{g}$ ), $\mathrm{m}_{50+1000}$ - is the mass of the fabric sample after each abrasion cycle (g)

Ambient conditions.

Ambient conditions for testing and preparation of fabric samples were in accordance with SRPS EN ISO 139 standard (relative air humidity $65 \% \pm 5 \%$, temperature $20^{\circ} \mathrm{C} \pm 2{ }^{\circ} \mathrm{C}$ ).

Table 2. Results for the percentage of changing the mass of the fabrics 1-6 during the abrasion test

\begin{tabular}{|c|c|c|c|c|c|c|c|c|c|c|}
\hline & \multirow[b]{2}{*}{$\Delta \mathbf{P}_{\mathrm{m}}$} & \multicolumn{5}{|c|}{ Dry sanding emery } & \multicolumn{4}{|c|}{ Waterproof emery } \\
\hline & & P240 & P180 & P150 & P120 & P80 & P500 & P360 & P240 & P180 \\
\hline \multirow{5}{*}{$\begin{array}{l}\overline{0} \\
\frac{0}{\frac{0}{2}} \\
\text { एँ }\end{array}$} & $\Delta \mathrm{P}_{\mathrm{m} 50}(\%)$ & 0.92 & 0.93 & 1.03 & 1.24 & 1.26 & 0.54 & 0.68 & 0.76 & 0.78 \\
\hline & $\vdots$ & $\vdots$ & $\vdots$ & $\vdots$ & $\vdots$ & $\vdots$ & $\vdots$ & $\vdots$ & $\vdots$ & $\vdots$ \\
\hline & $\Delta \mathrm{P}_{\mathrm{m} 300}(\%)$ & 1.1 & 1.21 & 1.46 & 2.56 & 3.21 & 1.03 & 1.35 & 1.51 & 1.53 \\
\hline & $\vdots$ & $\vdots$ & $\vdots$ & $\vdots$ & $\vdots$ & $\vdots$ & $\vdots$ & $\vdots$ & $\vdots$ & $\vdots$ \\
\hline & $\Delta \mathrm{P}_{\mathrm{m} 1000}(\%)$ & 1.74 & 1.78 & 2.70 & 5.14 & 9.38 & 1.51 & 1.94 & 2.25 & 2.53 \\
\hline \multirow{5}{*}{$\begin{array}{l}N \\
\text { N } \\
\text { 은 } \\
\stackrel{N}{\mathbb{N}}\end{array}$} & $\Delta \mathrm{P}_{\mathrm{m} 50}(\%)$ & 0.57 & 0.64 & 0.7 & 0.95 & 1.05 & 0.83 & 0.85 & 0.93 & 1.04 \\
\hline & $\vdots$ & $\vdots$ & $\vdots$ & $\vdots$ & $\vdots$ & $\vdots$ & $\vdots$ & $\vdots$ & $\vdots$ & $\vdots$ \\
\hline & $\Delta \mathrm{P}_{\mathrm{m} 300}(\%)$ & 1.39 & 1.59 & 1.99 & 2.89 & 3.67 & 1.62 & 1.82 & 2.11 & 2.29 \\
\hline & $\vdots$ & $\vdots$ & $\vdots$ & $\vdots$ & $\vdots$ & $\vdots$ & $\vdots$ & $\vdots$ & $\vdots$ & $\vdots$ \\
\hline & $\Delta \mathrm{P}_{\mathrm{m} 1000}(\%)$ & 2.91 & 3.05 & 4.17 & 6.84 & 9.97 & 2.82 & 3.20 & 4.09 & 4.45 \\
\hline \multirow{3}{*}{ 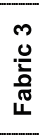 } & $\Delta \mathrm{P}_{\mathrm{m} 50}(\%)$ & 1.42 & 1.44 & 1.49 & 1.75 & 1.89 & 1.75 & 1.79 & 1.81 & 1.92 \\
\hline & $\Delta \mathrm{P}_{\mathrm{m} 300}(\%)$ & 1.82 & $\begin{array}{c}\vdots \\
1.92\end{array}$ & 1.94 & 2.84 & $\begin{array}{c}\vdots \\
3.96\end{array}$ & $\begin{array}{c}\vdots \\
2.36\end{array}$ & $\begin{array}{c}\vdots \\
2.4\end{array}$ & 2.54 & $\begin{array}{c}\vdots \\
2.63\end{array}$ \\
\hline & $\begin{array}{c}\vdots \\
\Delta \mathrm{P}_{\mathrm{m} 1000}(\%)\end{array}$ & 2.33 & $\begin{array}{c}\vdots \\
2.96\end{array}$ & $\begin{array}{c}\vdots \\
3.02\end{array}$ & $\begin{array}{c}\vdots \\
6.14\end{array}$ & $\begin{array}{l}\vdots \\
-\end{array}$ & $\begin{array}{c}\vdots \\
3.22\end{array}$ & $\begin{array}{c}\vdots \\
3.32\end{array}$ & $\begin{array}{c}\vdots \\
3.75\end{array}$ & $\begin{array}{c}\vdots \\
3.97\end{array}$ \\
\hline \multirow{5}{*}{$\begin{array}{l}\text { 寸 } \\
\text { 은 } \\
\text { 음 } \\
\stackrel{1}{1}\end{array}$} & $\Delta \mathrm{P}_{\mathrm{m} 50}(\%)$ & 0.47 & 0.62 & 0.76 & 0.89 & 1.07 & 0.42 & 0.52 & 0.61 & 0.62 \\
\hline & $\vdots$ & & $\vdots$ & $\vdots$ & $\vdots$ & $\vdots$ & $\vdots$ & $\vdots$ & $\vdots$ & $\vdots$ \\
\hline & $\Delta \mathrm{P}_{\mathrm{m} 300}(\%)$ & 0.82 & 0.89 & 1.62 & 2.42 & 3.15 & 0.95 & 1.08 & 1.33 & 1.62 \\
\hline & $\vdots$ & $\vdots$ & $\vdots$ & $\vdots$ & $\vdots$ & $\vdots$ & $\vdots$ & $\vdots$ & $\vdots$ & $\vdots$ \\
\hline & $\Delta \mathrm{P}_{\mathrm{m} 1000}(\%)$ & 1.61 & 2.03 & 3.38 & 5.41 & 10.32 & 1.55 & 1.75 & 2.52 & 2.89 \\
\hline \multirow{5}{*}{$\begin{array}{l}\text { n } \\
\text { 은 } \\
\text { 음 } \\
\text { ய. }\end{array}$} & $\Delta \mathrm{P}_{\mathrm{m} 50}(\%)$ & 1.23 & 1.3 & 1.32 & 1.61 & 1.64 & 1.53 & 1.57 & 1.58 & 1.59 \\
\hline & $\vdots$ & $\vdots$ & $\vdots$ & $\vdots$ & $\vdots$ & $\vdots$ & $\vdots$ & $\vdots$ & $\vdots$ & $\vdots$ \\
\hline & $\Delta \mathrm{P}_{\mathrm{m} 300}(\%)$ & 2.55 & 2.63 & 2.99 & 4.14 & 4.7 & 2.64 & 2.74 & 2.87 & 2.9 \\
\hline & $\vdots$ & . & $\vdots$ & $\vdots$ & $\vdots$ & $\vdots$ & $\vdots$ & $\vdots$ & $\vdots$ & $\vdots$ \\
\hline & $\Delta \mathrm{P}_{\mathrm{m} 1000}(\%)$ & 4.39 & 4.55 & 6.18 & 9.83 & 12.9 & 3.78 & 4.49 & 4.52 & 4.93 \\
\hline \multirow{4}{*}{ 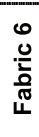 } & $\Delta \mathrm{P}_{\mathrm{m} 50}(\%)$ & 1.53 & 1.61 & 1.72 & 2.1 & 2.42 & 1.28 & 1.37 & 1.42 & 1.51 \\
\hline & $\vdots$ & & $\vdots$ & $\vdots$ & & $\vdots$ & $\vdots$ & $\vdots$ & $\vdots$ & $\vdots$ \\
\hline & $\Delta \mathrm{P}_{\mathrm{m} 300}(\%)$ & 2.89 & $\begin{array}{l}3.44 \\
:\end{array}$ & 3.92 & $\begin{array}{c}5.92 \\
:\end{array}$ & $\begin{array}{c}8.57 \\
:\end{array}$ & $\begin{array}{c}2.56 \\
:\end{array}$ & $\begin{array}{c}2.91 \\
:\end{array}$ & 3.44 & $\begin{array}{c}3.9 \\
:\end{array}$ \\
\hline & $\Delta P_{m 1000}(\%)$ & 6.88 & 7.44 & 10.43 & 14.14 & - & 5.6 & 7.01 & 9.54 & 10.86 \\
\hline
\end{tabular}


Table 3. Results for percentage of changing the mass of the fabrics $7-12$ during abrasion test

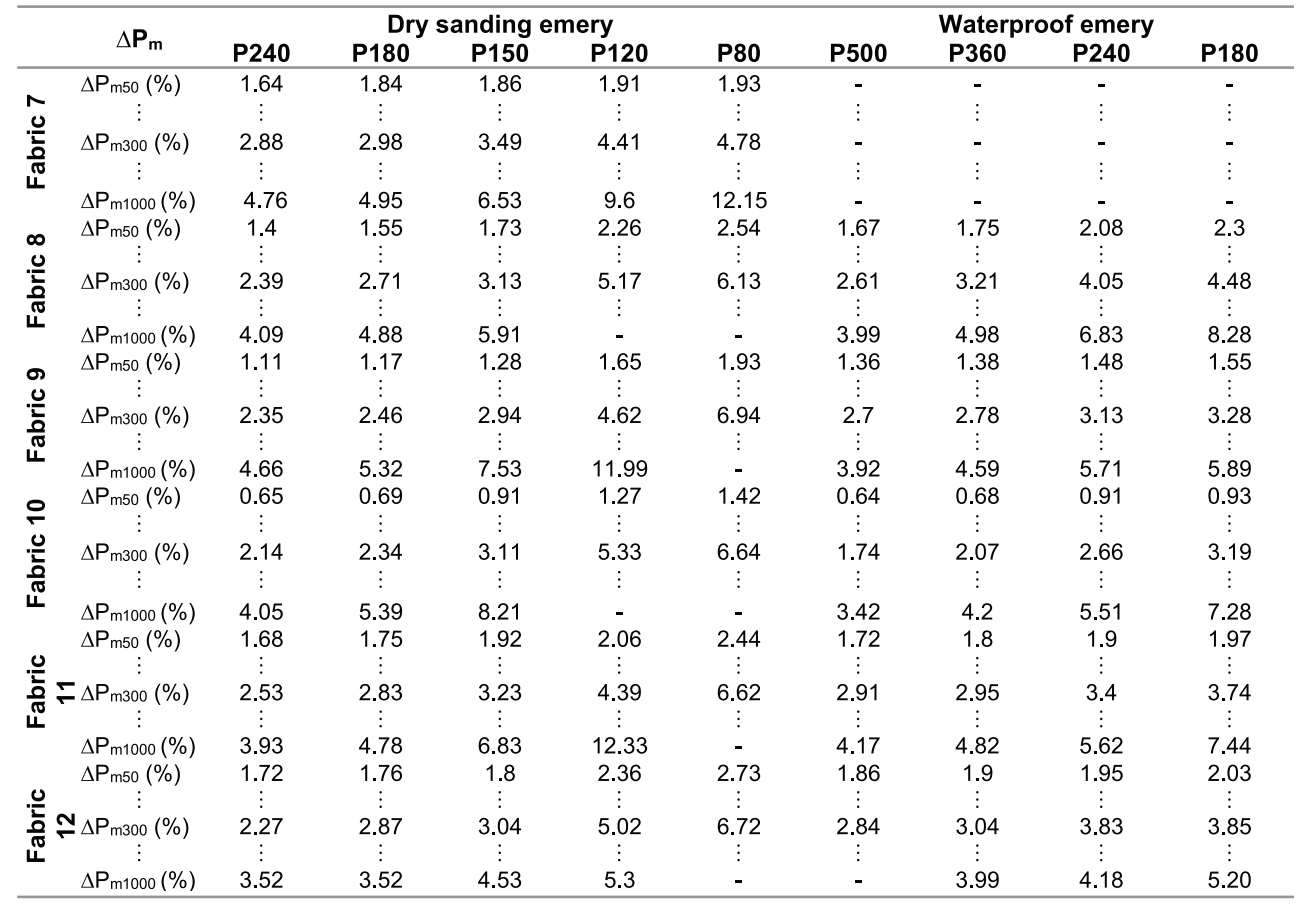

(a)

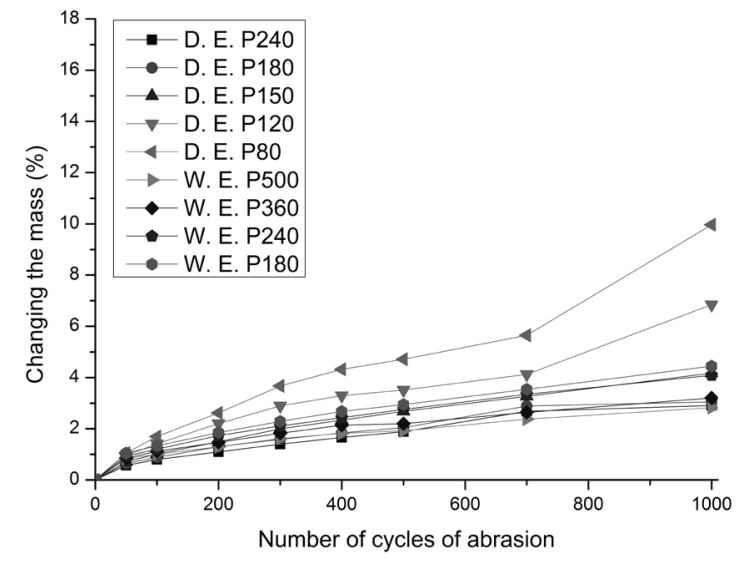

(b)

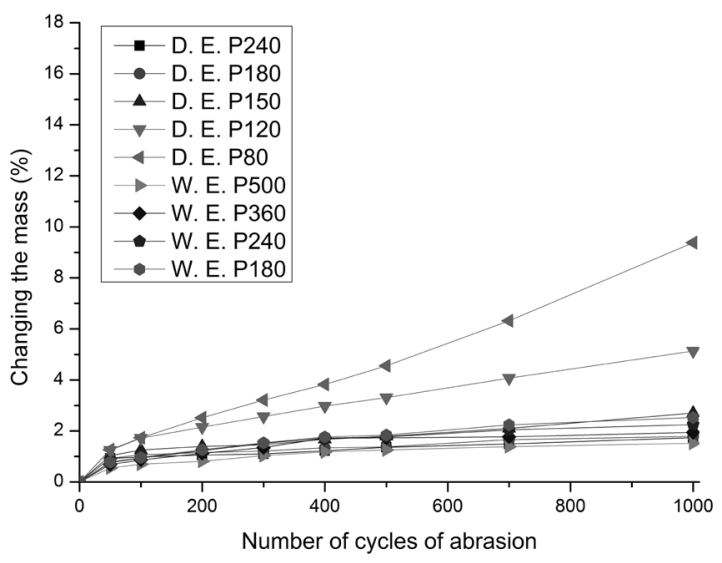

Figure 1. Percentage of changing the mass as dependent on the number of abrasion cycles of fabrics 1 (a) and 2 (b)

(a)

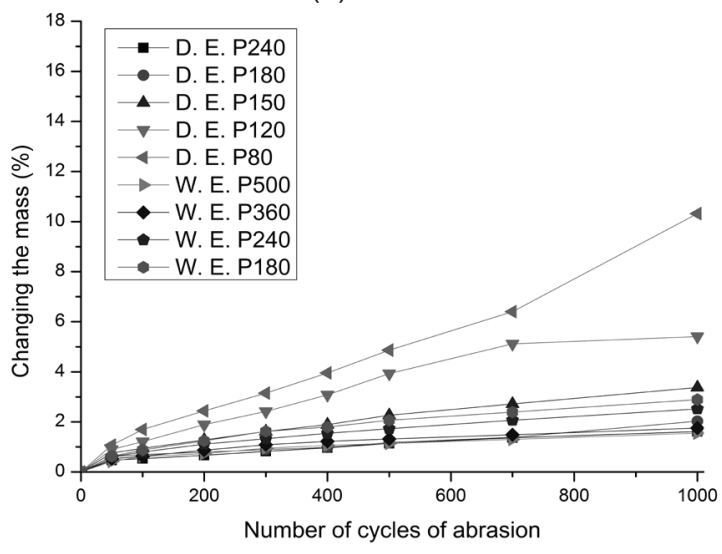

(b)

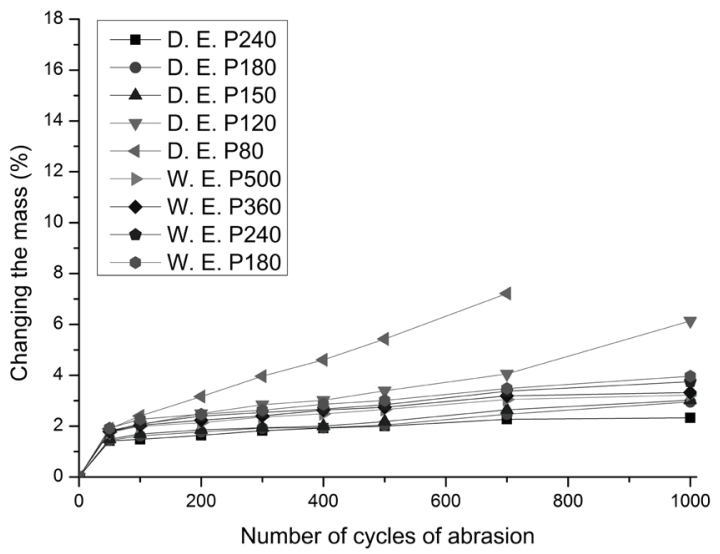

Figure 2. Percentage of changing the mass as dependent on the number of abrasion cycles of fabrics 3 (a) and 4 (b) 
(a)

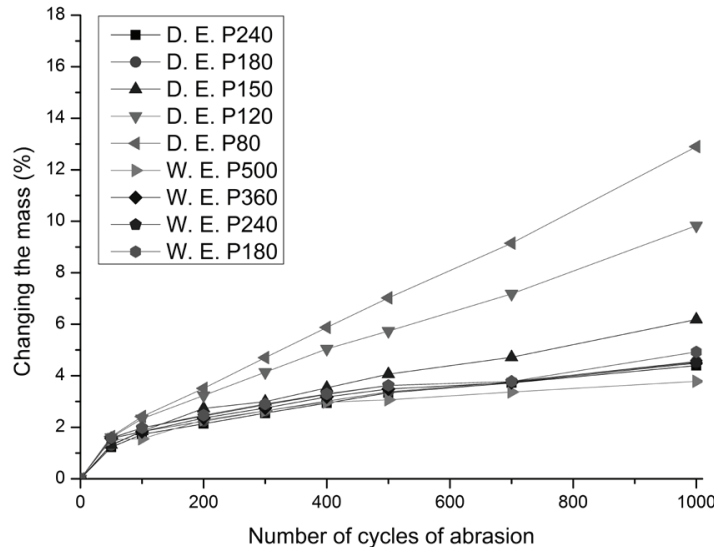

(b)

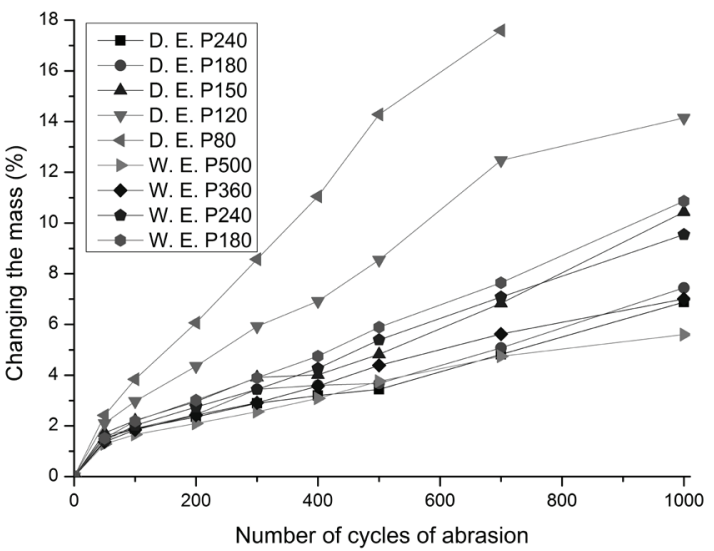

Figure 3. Percentage of changing the mass as dependent on the number of abrasion cycles of fabrics 5 (a) and 6 (b)

(a)

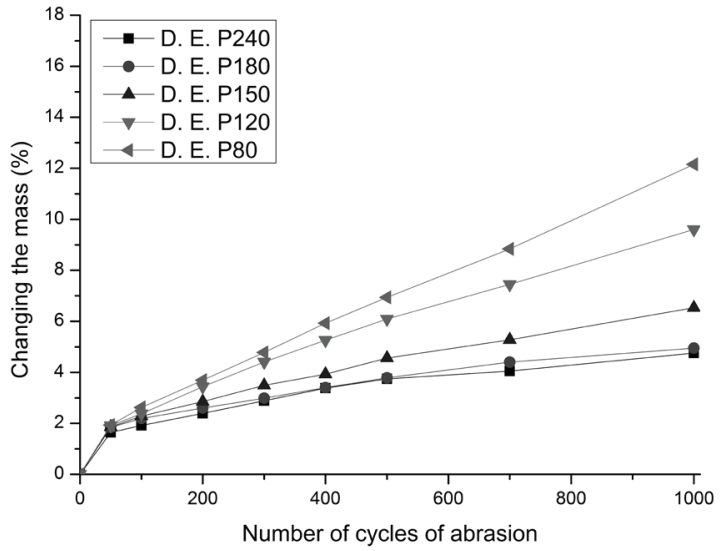

(b)

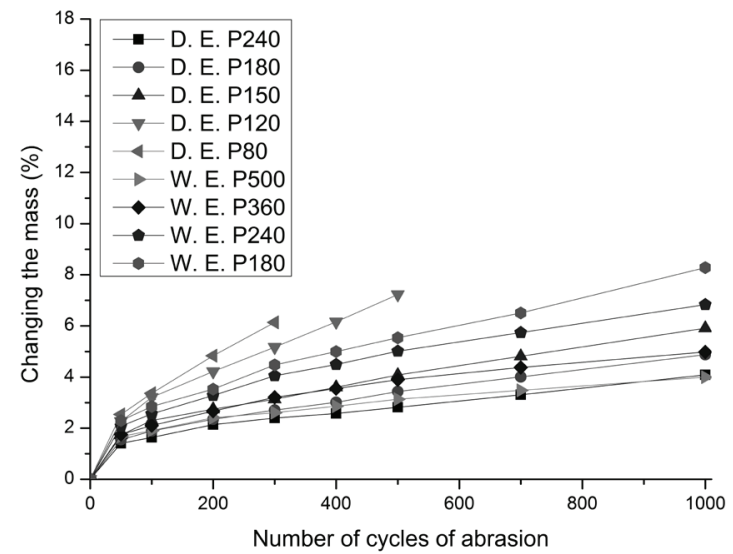

Figure 4. Percentage of changing the mass as dependent on the number of abrasion cycles of fabrics 7 (a) and 8 (b)

(a)

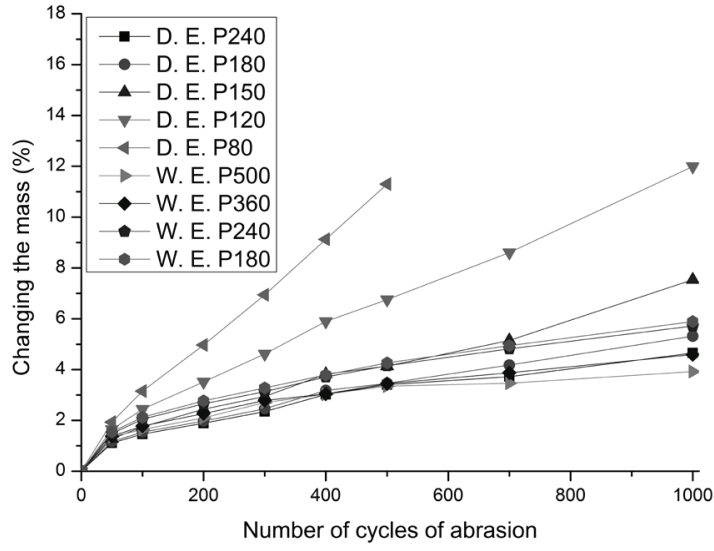

(b)

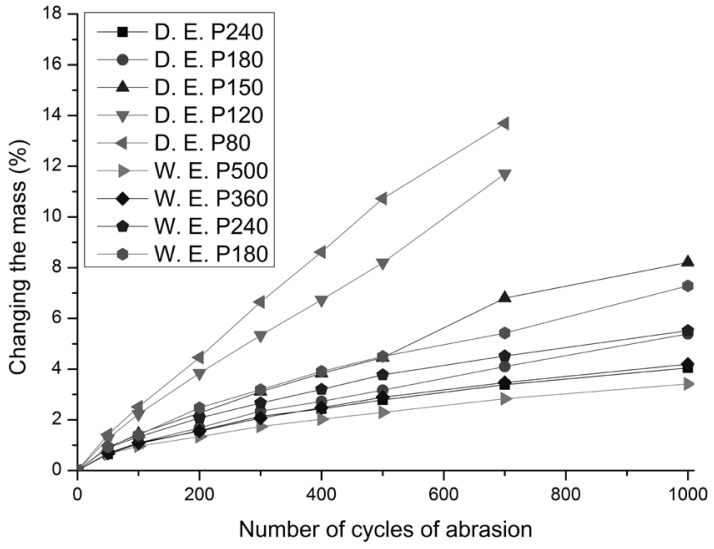

Figure 5. Percentage of changing the mass as dependent on the number of abrasion cycles of fabrics 9 (a) and 10 (b)

\section{Results and Discussion}

Results of resistance to wear of fabrics when treated with abrasive materials (two types of emery paper of different grit sizes are given in Tables 2 and 3 expressed as percentage of the mass change (mass loss). Due to the large number of results, the Tables present the percent- age of the mass change at 50, 300 and 1000 abrasion cycles.

In Figures 1 through 6 shown are the percentages of changing the mass for all fabric samples according to number of abrasion cycles. 
(a)

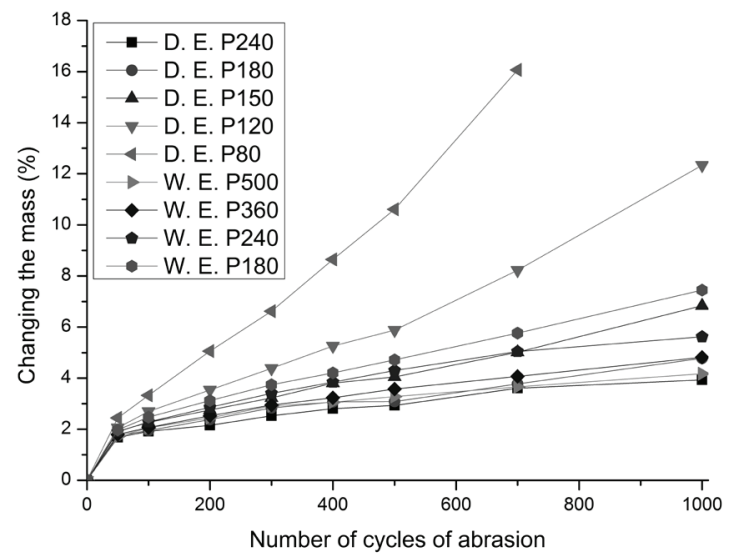

(b)

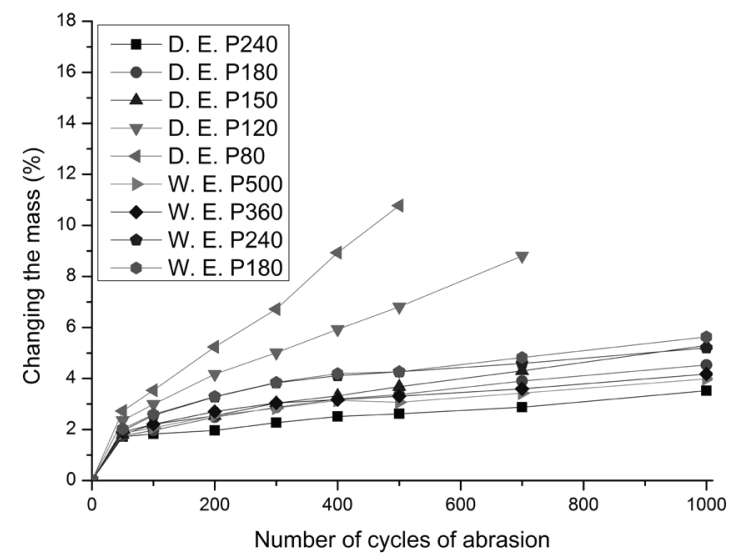

Figure 6. Percentage of changing the mass as dependent on the number of abrasion cycles of fabrics (11 (a) and 12 (b)

In Figure 7 the percentage of changing the mass of all fabrics treated with abrasion material D.E. P180 after 1000 abrasion cycles is given, and in Figure 8 the percentage of changing the mass for fabric samples 1,2 , 11 , and 12 treated with the abrasive material W.E. P180, also after 1000 abrasion cycles is presented.

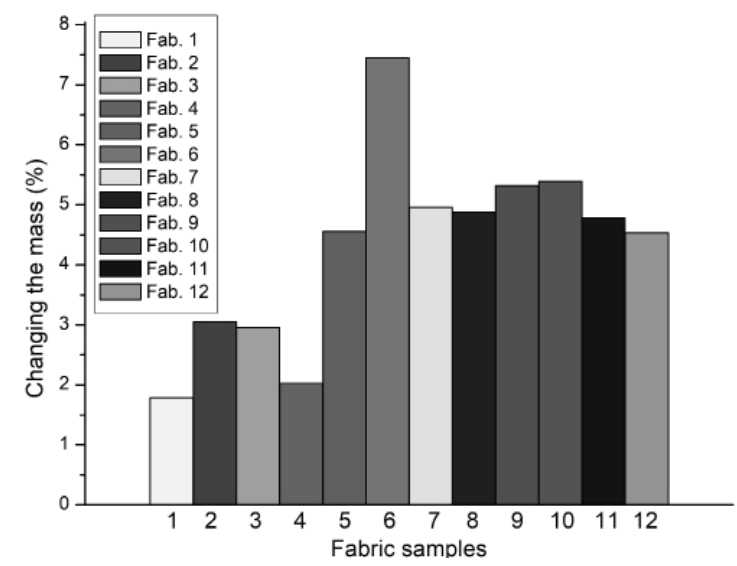

Figure 7. Percentage of changing the mass for all fabric samples (D.E. P180, 1000 cycles)

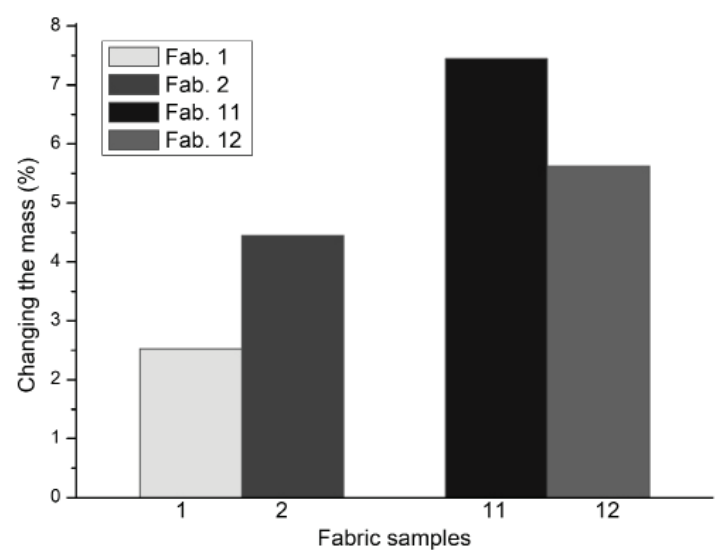

Figure 8. Percentage of changing the mass for fabrics 1, 2, 11, and 12 (W.E. P180, 1000 cycles)

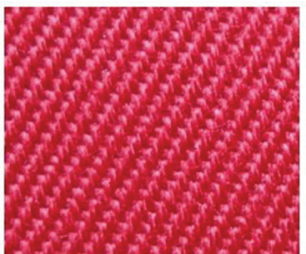

a)

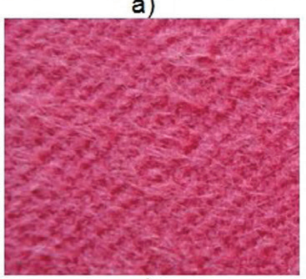

c)

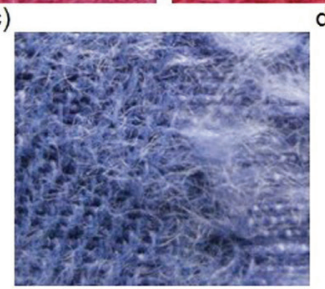

e)

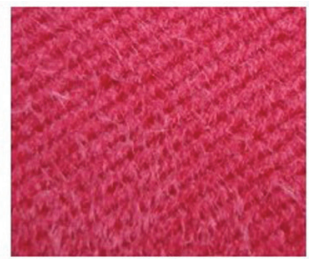

b)

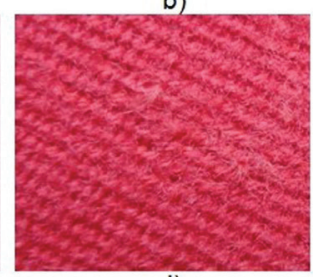

d)
Figure 9. The appearance of samples of fabric 5 (a through d) and $6(\mathrm{e})$

All the samples of fabric were visually observed and compared to the untreated sample of the same fabric after each cycle of abrasion. Figure 9 shows the appearance of fabric 5 (before and after abrasion, a) through d) and 6 (after the abrasion, e). Under a) is the untreated sample of fabric $5, b$ ) a sample of fabric 5 treated with abrasive D.E. P180 after 300 cycles of abrasion, c) a sample of fabric 5 treated with abrasive D.E. P180 after 1000 cycles of abrasion, d) a sample of fabric 5 treated with abrasive W.E. P180 after 1000 cycles of abrasion, e) a sample of fabric 6 treated with abrasive D.E. P180 after 700 cycles of abrasion.

Discussion.

From the selected fabrics for making protective gar- 
ments, fabrics 1,3 and 4 (lower percentage of loss of weight) exhibit the best results in terms of resistance to wear. Fabrics 1 and 3 are made of twisted cotton yarns in plain weave, while fabric 4 is made of twisted yarn from the mixture of cotton and polyester fiber in 2/1 twill weave. Thanks to the structure of the yarn, and the way yarns are interlacing in the fabric, fibers in the yarn cling more tightly to one another and also yarns are more tightly linked. Therefore, there is greater resistance to abrasion in these fabrics compared to others. In the third fabric the fiber composition shows a great influence and annuls the advantages of the plain weave in relation to other interlaces (Figure 7). Fabrics 1 and 2 have the same surface mass, and they are both in plain weave, but due to structural and constructive solutions of the yarns and fabric, fabric 1 has better abrasion resistance (Figure 8).

Fabrics made in plain weave show better resistance to abrasion thanks to a smaller flotation of weft and warp wires since the contact surface with the abrasive material is smaller.

Regarding the influence of fineness of sandpaper on the value of the resistance of fabrics to wear, abrasive paper with smaller numbers (P120 and P80), unlike others, make more damage to the material. These abrasive grits are coarser i.e. bigger and cover more fibers during friction, which causes more damage to the fabric.

It is interesting that, when using the same fineness of abrasive materials and different methods of their preparation, different results for percentage of weight loss of fabric samples are obtained. When using the so-called waterproof sandpaper, a higher percentage of loss of weight is obtained compared to the application of the so-called dry sandpaper. The waterproof abrasive paper granules (although smaller) have sharper edges and cause more damage during the friction against fabric, cutting the fibers on the surface. Thereby the thickness of the fabric is reduced and its mechanical properties are damaged and reduced.

As for fabrics 11 and 12 with satin weave, fabric 12 has better wear resistance even though single-wire yarn (but with smaller count) was applied as the warp, compared to twisted yarn used for fabric 11 (which has larger count). The samples with yarns of smaller count (other features being similar) have less damage because they have a smaller contact area with the abrasive material. Fabric 12 also has a higher warp density and this feature also affects the abrasion resistance of the fabric (Figure 8).

Comparing the changes in the weight loss with the number of cycles of abrasion it can be seen that the mass loss of the samples increases (columns in the Table and graphs in the pictures). Greater changes of the weight loss were observed in all samples except for 1, 3 and 4 where the change of the mass loss was lower due to the above mentioned reasons. For all samples, the highest change of mass as related to the number of cycles was at the beginning of abrasion (number of cycles 50 ). By increasing the number of cycles, the change of mass is less to some extent, until the material damage becomes visible. One of the reasons is the change of the rubbing surface of the abrasive material (abrasive material is consumed over time) with increasing the number of cycles.

In all fabrics a visible damage occurred after 1000 cycles (yarn breaks, the occurrence of holes in the fabric), except in some samples $(3,6,8,9,10,12)$ which were treated with sandpaper D. E. P120 and D. E. P80 where the damage appeared earlier (Figure 9). As for fabrics 5, $6,7,8,10$ and 11 , with the number of cycles of about 700 and above, there was somewhat greater damage - loss of weight - than with other fabrics, and these fabrics can be used, for example, to make protective work garments that have less contact with abrasive materials and objects with rough surfaces during work.

\section{Conclusions}

Abrasion resistance is the resistance by which the fabric (textile material) opposes degradation and it is influenced by parameters such as the composition of the raw material, yarn type (single-fiber, twisted), weave, type of the finishing treatment, fineness and type of the abrasive material. Fabrics made of twisted yarn, of a blend of cotton and polyester fiber, yarn with lower count and those made in plain weave are characterized by higher resistance and less deformation - damage due to wear, compared to other tested fabrics.

Wear and tear is essentially a process explained by the plastic deformation whenever there is friction between two bodies and even textile materials. The testing may refer to the textile material only or the abrasion agent, or both simultaneously. The process of abrasion takes place a certain time without any visible damage and later the damage appears - the yarn breaks or the fabric tears. Resistance to wear is one of the important characteristics when choosing fabric for making working clothes. The durability of clothing will depend on these characteristics.

\section{Acknowledgements}

This work is a part of the research project No. TR34020, financed by the Ministry of Education, Science and Technological Development of the Republic of Serbia.

\section{References}

[1] M. Kulić, M. Somogyi Škoc, Komparativno ispitivanje habanja visokoučinkovitih tkanina u mokrom stanju, International Interdisciplinary Journal of Young Scientists from the Faculty of Textile Technology, 5(5) (2015) 33-41.

[2] J.E. Booth, Principles of Textile Testing, Heywood Books, London, 1970.

[3] R. Čunko, Ispitivanje tekstila, Tekstilno-tehnološki fakultet, Zagreb, 1989.

[4] M. Žišić, V. Mitić. Ispitivanje tekstila. VTTŠ, Leskovac 1981. 
[5] SRPS EN ISO 12947 - 1-4 (2008): Tekstil - Određivanje otpornosti tekstilnih površina prema habanju pomoću Martindelove metode

[6] ASTM D 3884 - 09 (2013): Test Method for Abrasion Resistence od Textile Fabric (Rotary Platform, Double Head Method)

[7] ASTM D 3885 - 07a (2015): Test Method for Abrasion Resistence od Textile Fabric (Flexing and Abrasion Method)
[8] C. Yahya, "Pilling Performance and Abrasion Characteristics of Plain-Weave Fabrics Made from Open - End and Ring Spun Yarns", Fibers \& Textiles in Eastern Europe, 16(1) (2008) 81-84.

[9] N. A. Kotb, Z. M. Abdel Megeid, Evaluation of Abrasion Behaviour of Knitted Fabrics under Different Paths of Martindale Tester, Journal of American Science, 7(7) (2011) 164-169.

Izvod

\section{ZNAČAJ OTPORNOSTI PREMA HABANJU U IZBORU TKANINE ZA ZAŠTITNE ODEVNE PREDMETE}

Nataša Radmanovac, Nenad Ćirković, Tatjana Šarac

\footnotetext{
Tehnološki fakultet, Univerzitet u Nišu, Leskovac, Srbija
}

Otpornost na habanje, kao jedna od karatkeristika, koristi se za ocenu trajnosti tekstilnih materijala pri upotrebi, odnosno njihove podobnosti za predviđenu namenu. $U$ radu su prikazani rezultati ispitivanja habanja tkanina namenjenih za izradu zaštitne i radne odeće, metodom po Martindaleu. Habanje tkanina je vršeno brusnim papirom po ravnoj površini, pri različitim ciklusima, praćenjem promene mase i vizuelnim poređenjem. Sa povećanjem broja ciklusa habanja može se videti da raste procentualni gubitak mase uzoraka zahvaljujući čupanju vlakana sa površine, a takođe može doći do oštećenja koje se vidi u prekidima pređa i pojava rupa na tkanini.
(ORIGINALNI NAUČNI RAD)

UDK 687.17:677.017

Ključne reči: tkanina, habanje, abrazivni materijal, promena mase 